\title{
YOUNG LEARNERS' MOTIVATION FOR READING IN ENGLISH AND THEIR READING ACHIEVEMENT
}

\begin{abstract}
Summary
Academic and professional success has never been so dependent on literacy skills in English as a foreign or second language (L2) as it is at the present time. Reading has become a crucial skill in terms of learning mainly due to the fast technological development and a vast body of information available in English on the internet. This situation is placing great demands for reading skill development even to young English language learners. Since young learners' confidence and motivation are found to contribute to their linguistic outcomes, the paper aims to study how young learners' motivation contributes to their reading skill development and reading achievement. A survey of reading skills and attitudes was conducted with a sample of 502 young English language learners (aged 11, primary Grade Five) from six state primary schools located in five distant towns in Serbia. Motivation and reading skills were investigated both quantitatively and qualitatively. Correlational analysis of these results showed that there was a statistically significant difference in reading outcomes in relation to motivation for L2 learning and to attitudes to different aspects of reading, while the interviews with a sub-sample of L2 learners indicated a crucial role of motivation for extensive reading and fluency development. The findings point to the key role of motivation for young learners' L2 literacy development and have significant pedagogical implications.
\end{abstract}

Key words: young learners, motivation for reading in English, beginning reading, reading achievement, prompted think-aloud protocol interviews.

\section{Introduction}

Although the role of motivation in learning English as a foreign/second language (L2) at a young age has widely been acknowledged (Cable et al. 2010; Dörnyei and Csizér 1998; Drew 2009; Edelenbos, Johnstone

*_verasavic035@gmail.com 
and Kubanek 2006; Enever 2011; Mihaljević Djigunović 2013, 2014; Mihaljević Djigunović and Lopriore 2011; Nikolov 1999, 2009; Pinter 2011; Saville-Troike 2006; Szpotowicz and Lindgren 2011), the significance of young learners' attitudes to and motivation for beginning reading in English as a foreign language has not been studied extensively. Correlational studies point to significant contribution of some individual factors to L2 reading outcomes and L2 proficiency, while for some factors "it is difficult to establish causality, or even directionality: for example, "good learners" may approach language tasks more actively because they are more proficient (not more proficient because they are more active), or because they are more self-confident" (Saville-Troike 2006, 92). Less successful language learners "often have lower self-esteem than successful language learners" (Oxford 2005, 62), comparing their L1 language skills to their L2 language skills and feeling rather limited. Since the role of attitude and motivation in beginning EFL reading development of young learners is indisputable (McKay 2006), it is of major importance to study the contribution of motivation to reading development and achievement of young children. The area is gaining in importance considering the fact that reading in English as a foreign/second language (L2) has become a critical skill not only in the development of academic competence and interpersonal communication, but also in scientific research and technological advancement (Grabe and Stoller 2011; Graddol 2006; Saville-Troike 2006).

\section{Motivation and reading in English as a foreign language}

Motivation can be defined as "the foundation of human behaviour" which involves motivational (interest), cognitive (curiosity and engagement) and emotional (joy) components responsible for " $w$ hy people decide to do something, how long they are willing to sustain the activity, and how hard they are going to pursue it" (Dörnyei 2014, 519-520). Motivation is considered to be a significant factor that can explain success and failure in learning a foreign or second language (L2) (Dörnyei 2014, 518), determine the effort learners put into their L2 development (Saville-Troike 2006, 85), and influence "the rate and success of L2 attainment" (Dörnyei and Csizér $1998,203)$. It is a rather complex concept involving interrelated factors 
like social attitudes, values, and other learner factors (Rasinger 2008, 20). Moreover, motivation integrates the factors related to the learner, the learning task, and the learning environment, thus making a conglomerate of L2 motivational self system, a term proposed by Dörnyei $(2014,520-521)$ as a mixture of the following three components: 1. ideal L2 self, i.e. desired future self-image; 2 . ought-to L2 self, i.e. attributes for avoiding possible negative outcomes; 3. L2 learning experience, i.e. situation-specific motives related to the learning environment, like positive influence of success or enjoyable quality of a language course.

Recent research has shown that the learning experience motivational component is the strongest factor in determining motivated behaviour, i.e. the more positive learners' experience with a foreign language is, the more effort they will put into their own language development (Piniel and Albert 2017, 92). Studies of children's L2 reading proficiency indicate that children's reading comprehension is influenced by their experience both in the native language (L1) and in L2 (Grabe and Stoller 2011, 49). Moreover, the development of oracy in a foreign language can enhance children's self-confidence when reading and writing in their L1 (Cable et al. 2010, 4). Two types of motivation should be recognized in L2 motivated behaviour: 1. integrative, in which emotional or affective factors are the most powerful, like interest in the society or people who use L2; 2 instrumental, involving practical reasons, like passing the L2 course in school, or having better study and employment opportunities (Saville-Troike 2006, 86). Research indicates that young learners' reading comprehension depends both on integrative and instrumental motivation (Wang and Guthrie 2004, 162), and that integrative motivation can affect the amount of reading and the development of children's reading comprehension (Grabe and Stoller 2011, 122). It has been argued that at primary level there is not a strong gender differentiation in relation to motivation and attitudes (Cable et al. 2010, 44), but some studies indicate a strong influence of societal factors on attitude, causing a sharp decrease of boys' positive attitude due to the influence of "media images and the opinions of their elder siblings and parents" (Enever 2009, 28).

Motivation has been reported to correlate highly with contextual factors that influence reading, like aspects of the learning environment, 
i.e. teacher, out-of-school exposure to L2 (like extensive reading), in a way that positive attitudes to these factors play a very important role in children's L2 learning. A contextual factor closely related to motivation and attitudes is the L2 teacher, whose role is of great significance in an L2 young learner classroom (Pinter 2011, 143), but the emotional link to the teacher weakens with the children's age, and the intrinsic motive for participating in class activities becomes more prominent (Nikolov 1999, 45). Another contextual factor that can affect children's attitudes to and motivation for reading in L2 is the classroom intervention focused on developing strategic reading in L2. Research indicates that such an intervention can result not only in more positive attitudes to reading in L2, but can also produce positive attitudes to other three language skills, as well as to the textbook and homework tasks (Macaro and Erler 2008, 111). Studies of interaction between contextual and individual factors with linguistic outcomes in early EFL learning have found that both contextual factors (e.g. learning environment, out-of-school exposure to English, socio-economic status, home support) and individual factors (e.g. attitudes, motivation, and linguistic self-confidence) affect the linguistic outcomes of children (Mihaljević Djigunović 2013, 172-175). What is more, interactions of contextual and individual factors with linguistic outcomes change with time, becoming rather dynamic, with motivation appearing to be unstable, fluctuating with time due to a feeling of achievement, so that motivation for learning new words decreases over time, while reading as a classroom activity gains popularity (Mihaljević Djigunović 2013, 172-175). It seems that with maturity, children's preferences change from fun activities to skills-related activities, and that their motivation for reading increased as a result of "a sense of achievement in reading [and] their growing cognitive development" (Mihaljević Djigunović and Lopriore 2011, 47).

To sum up, the studies indicate strongly that individual factors like attitudes and motivation are closely linked to contextual factors, interact with each other and with reading outcomes of young learners, and stress the importance of comparative research of their interrelations in a variety of contexts worldwide. This study aims to contribute to the body of research in this field. 


\section{Study}

The paper reports part of a large-scale study of young learners' reading difficulties in English as L2 (Savić 2014).

\section{Aim and research questions}

The principal aim of the study was to investigate how young learners' attitudes and motivation contribute to their reading skill development and reading achievement. Based on the above literature review, four research questions were posed: 1 . What is the correlation between motivation for learning English and young learners' reading achievement?; 2. What is the correlation between motivation for reading in English and young learners' reading achievement?; 3 . What is the correlation between children's attitudes to different reading formats (reading aloud, reading silently, reading on the internet) in English and their reading achievement?; and 4. How do motivation and attitudes correlate with each other? It was hypothesised that there was a significant correlation between the participants' motivation for and positive attitudes to learning English and reading in English and their success in reading, and that motivations and attitudes correlated significantly with each other.

\section{Method}

To investigate the interrelationship between motivation and reading achievement a mixed method was applied, and both quantitative and qualitative data was collected and analysed.

\section{Participants}

The target population in our study were young learners $(\mathrm{N}=502)$ aged 11, learning English as a foreign language in six geographically distant state primary schools in Serbia. The survey was done after four full years of their English language study, of which two years involved the development of reading in English (Savić and Stanojević 2016, 358). A sub-sample of twelve young learners comprised an interview group. 


\section{Instruments}

Three instruments were used to measure reading success and to survey motivation and attitudes: 1. reading research tool (a comic strip with seven multiple-choice items with distracters, created by the Early Languages Learning in Europe (ELLiE) Team (Enever 2011), administered to the whole sample; 2. three-point rating scale (smiley questionnaire) with five items for surveying motivation and attitudes, administered to the whole sample; and 3. prompted think-aloud protocol interview for collecting data through a semi-structured interview with the sub-sample (conducted in L1).

\section{Procedure}

The study was performed during school visits by the researcher. The schools and EFL teachers had previously been contacted and they agreed in writing to take part in the study. Consent forms signed by the parents of twelve participants (sub-sample) had been obtained before the interviews.

\section{Data analysis}

Data collected through the reading research tool and the smiley questionnaire were analysed with the SPSS package, while the prompted think-aloud protocols were audio recorded and transcribed, and analysed through repeated content patterns. The correct responses in the reading test were allocated one point each (max. 7 points), while the three-point scales were assigned numerical values (a smiley face $=3$ points, a neutral face $=$ 2 points, a sad face $=1$ point $)$.

\section{Results and discussion}

Table 1 summarises the reading test results for the sample in six schools involved in the survey. The mean score in the reading test was $\mathrm{M}=4.75$ (total scores ranged from 0 to 7 ), $\mathrm{SD}=1.84$, and there was no difference in reading outcomes in relation to gender of the learners $(p=.565)$ (Savić 2014, 111). For the six schools involved in the research study, the 
reading task results ranged from $M=4.40$ (for School 2) to $M=5.54$ (for School 6), with standard deviations between $\mathrm{SD}=1.67$ (for School 6) and $\mathrm{SD}=1.97$ (for School 2). The Serbian young learners' achievement rates are found to be comparable to the achievement of young learners in the ELLiE study, in which "the total mean result is 4.1 and mean values in different contexts range from 2.8 to 5.5" (Munoz and Lindgren 2011, 113).

Table 1. Reading test results per school and per the whole sample (means and standard deviations).

\begin{tabular}{|l|c|c|c|}
\hline School & Participants (N) & Mean (min. 0, max. 7) & Std. Deviation \\
\hline School 1 & 80 & 4.94 & 1.80 \\
\hline School 2 & 85 & 4.40 & 1.97 \\
\hline School 3 & 75 & 4.43 & 1.73 \\
\hline School 4 & 71 & 4.51 & 1.92 \\
\hline School 5 & 101 & 4.57 & 1.73 \\
\hline School 6 & 90 & 5.54 & 1.67 \\
\hline Total & 502 & 4.75 & 1.84 \\
\hline
\end{tabular}

The results for participants' motivation for learning English and reading in English, and for their attitudes to reading aloud in English, to reading silently in English, and to reading on the internet, are summarised in Table 2. The data obtained show that the participants' motivation for learning English and for reading in English is high $(\mathrm{M}=2.75, \mathrm{SD}=.533$, and $\mathrm{M}=2.79, \mathrm{SD}=.493$, respectively), and that they hold highly positive attitudes to different modes of reading in English, with the scores ranging from $\mathrm{M}=2.42, \mathrm{SD}=.782$, to $\mathrm{M}=2.50, \mathrm{SD}=.744$. These data have already been reported by Savić and Stanojević (2016, 358-359) in the study of interrelationship of self-esteem and attitudes of the same sample.

Table 2. Summary of mean values and standard deviations for motivation and attitudes.

\begin{tabular}{|l|c|c|c|c|c|}
\hline & $\mathrm{N}$ & Minimum & Maximum & Mean & Std. Deviation \\
\hline Learning English & 502 & 1 & 3 & 2.75 & .533 \\
\hline Reading in English & 502 & 1 & 3 & 2.79 & .493 \\
\hline Reading aloud in English & 502 & 1 & 3 & 2.50 & .744 \\
\hline Reading silently in English & 502 & 1 & 3 & 2.48 & .778 \\
\hline Reading on the internet & 502 & 1 & 3 & 2.42 & .782 \\
\hline
\end{tabular}


The results in relation to individual aspects will first be discussed separately and then correlated with each other and with the reading scores to provide the answers to the research questions. Table 3 compares the frequencies/percentages for motivation and attitudes for all items in the smiley questionnaire.

Table 3. Summary of frequencies/percentages for motivation and attitudes

\begin{tabular}{|l|l|c|c|c|}
\hline \multirow{2}{*}{ Item } & & \multicolumn{3}{|c|}{ Responses } \\
\cline { 3 - 5 } & & no & not sure & yes \\
\hline \multirow{2}{*}{ Do you like learning English? } & frequency & 24 & 78 & 400 \\
\cline { 2 - 5 } & percent & 4.78 & 15.54 & 79.68 \\
\hline \multirow{2}{*}{ Do you like reading in English? } & frequency & 19 & 68 & 415 \\
\cline { 2 - 5 } & percent & 3.78 & 13.55 & 82.67 \\
\hline \multirow{2}{*}{ Do you like to read aloud in English? } & frequency & 76 & 98 & 328 \\
\cline { 2 - 5 } & percent & 15.14 & 19.52 & 65.34 \\
\hline \multirow{2}{*}{ Do you like to read silently in English? } & frequency & 89 & 85 & 328 \\
\cline { 2 - 5 } & percent & 17.73 & 16.93 & 65.34 \\
\hline \multirow{2}{*}{ Do you like to read in English on the internet? } & frequency & 92 & 106 & 304 \\
\cline { 2 - 5 } & percent & 18.33 & 21.12 & 60.56 \\
\hline
\end{tabular}

A great majority of the participants expressed their motivation for learning English and reading in English (79.68\% and 82.67\%, respectively). Surprisingly, more participants expressed motivation for reading in English than for learning English. This finding is in line with the studies that showed highly positive attitudes to reading in L2 expressed by older children as a result of their cognitive development and sense of achievement (Mihaljević Djigunović and Lopriore 2011, 47). Interestingly, the same number of the participants expressed a positive attitude to reading aloud and to reading silently (65.34\%), though a slightly greater number declared they did not like reading silently $(17.73 \%)$ as compared to the number of the participants who did not like reading aloud (15.14\%). A possible reason for this may be the fact that beginning readers may need the aural support to enhance understanding, or that their aural learning style slightly prevails over their visual learning style. Popularity of reading aloud with beginning readers is expected, as reading aloud is the main mode of reading practice in the classroom as a way of providing teachers with feedback on their learners' reading development.

Prompted think-aloud protocols with the sub-sample provided more detailed data related to attitudes to reading aloud and reading silently. The 
respondents' preferences were different in relation to oral and silent reading, seven of them expressing preference for reading aloud, and five for reading silently. The preference for oral reading was supported with the following arguments: "Reading aloud helps me understand better." (L-1-1-2-13, L-1-1-1-08, L-2-2-1-15, L-4-1-1-10), "I prefer listening to myself reading in English to being silent while reading." (L-2-1-2-03), "I understand better when reading aloud because words are more successful in making images in my mind when I read aloud." (L-5-1-2-09), "It's easier to understand when you say the words." (L-5-1-1-27). Another respondent (L-4-1-1-10) added that he or she was confused when reading silently. One respondent preferred reading aloud, but added: "I think I understand better when I read silently. ... For me the most important thing is to know what something means, not how it sounds. Of course, it is important how I pronounce words, but I think it is more important to know what something means than how it sounds." (L-2-12-03). The preferences for silent reading were supported with the following arguments: "I find reading silently easier." (L-2-1-1-02); "I prefer reading silently because I can focus on meaning and understanding." (L-3-1-3-16); "I prefer reading silently because I understand better that way." (L-3-1-3-05, L-4-1-1-09); "I prefer reading silently because I have more time to think about the meaning of the text." (L-3-1-3-21).

Not surprisingly, reading on the internet was the least preferred mode of reading in English (60.56\% expressed a positive attitude). Prompted think-aloud protocol interviews with twelve focal participants yielded similar results. The respondents' attitudes to reading on the internet were mostly favourable: nine of them liked reading in English on the internet, one was undecided, and two were not fond of it. However, although nine of the respondents reported motivation for reading in English on the internet, the internet was reported as a regular source of reading material in English only by six of the respondents. Some reasons for not reading on the internet more often were also reported by the sub-sample, who reported being unable to surf the internet successfully: "I may try to find an interesting text on the internet by myself, but I think I will need help to do it." (L-1-1-2-13). Other possible reasons for this may include the fact that reading on the internet is an out-of-school activity and a mode of extensive reading that depends on accessibility of the internet and on the participants' independence in reading in English, not to be expected at this level of L2 development. Also, internet 
material is not graded (unlike most of the classroom material read aloud or silently both in school and at home), which may further hinder children's motivation for reading in English on the internet.

However, one of the respondents (L-5-1-2-09) reported spending 7-8 hours a day playing video games online and reading on the internet, while communicating with other gamers worldwide; this activity resulted in almost native-like pronunciation of English, extremely few errors (miscues) in reading aloud, and a high level of comprehension of the text read in the thinkaloud. Another respondent (L-5-1-1-27) reported reading often on the internet to get the information for school assignments and feeling very motivated to read on the internet if he or she found the texts comprehensible.

Correlational analysis was conducted to determine how motivation and attitudes affected reading scores and how they were interrelated. The results will be presented in the sequence of research questions. Table 4 shows correlation of reading test outcomes with motivation for learning English and reading in English.

Table 4. Correlation of reading test outcomes with motivation for learning English and reading in English.

\begin{tabular}{|c|c|c|}
\hline \multirow{2}{*}{ Item } & \multicolumn{2}{|c|}{ Test statistics } \\
\hline & & Reading test results \\
\hline \multirow{3}{*}{ Do you like learning English? } & Chi-Square & 10.952 \\
\hline & $\mathrm{df}$ & 2 \\
\hline & Asymp. Sig. & .004 \\
\hline \multirow{3}{*}{ Do you like reading in English? } & Chi-Square & 30.201 \\
\hline & $\mathrm{df}$ & 2 \\
\hline & Asymp. Sig. & .000 \\
\hline \multirow{3}{*}{$\begin{array}{l}\text { Do you like to read aloud in } \\
\text { English? }\end{array}$} & Chi-Square & 21.970 \\
\hline & $\mathrm{df}$ & 2 \\
\hline & Asymp. Sig. & .000 \\
\hline \multirow{3}{*}{$\begin{array}{l}\text { Do you like to read silently in } \\
\text { English? }\end{array}$} & Chi-Square & 2.585 \\
\hline & $\mathrm{df}$ & 2 \\
\hline & Asymp. Sig. & .275 \\
\hline \multirow{3}{*}{$\begin{array}{l}\text { Do you like to read in English } \\
\text { on the internet? }\end{array}$} & Chi-Square & 16.183 \\
\hline & $\mathrm{df}$ & 2 \\
\hline & Asymp. Sig. & .000 \\
\hline
\end{tabular}


Research questions 1, 2 and 3. Correlational analysis of the results related to the participants motivation and attitudes and their reading outcomes shows that there is a considerable difference in reading outcomes in relation to all items, except in relation to the attitude to reading silently in English. There is a significant difference in reading test results in relation to motivation for learning English $(p=.004)$, motivation for reading in English $(p=.000)$, the attitude for reading aloud in English $(p=.000)$ and for reading on the internet $(\mathrm{p}=.000)$, but there is no difference in reading test results in relation to the attitude to reading silently in English ( $p=.275)$.

The findings show that there was a significant difference in reading results of the learners based on their motivation, which provides additional insight into previous findings of correlation of linguistic results and motivation (Mihaljević Djigunović 2013; Mihaljević Djigunović and Lopriore 2011).

Research question 4. Table 5 presents correlational analysis of motivation for learning English and attitudes to reading in English and shows statistical significance of their interrelations.

Table 5. Correlational analysis of motivation for learning English and attitudes to reading in English.

\begin{tabular}{|c|c|c|c|c|c|}
\hline Items & & $\begin{array}{l}\text { Reading } \\
\text { in English } \\
\end{array}$ & $\begin{array}{l}\text { Reading aloud } \\
\text { in English }\end{array}$ & $\begin{array}{l}\text { Reading silently } \\
\text { in English }\end{array}$ & \\
\hline \multirow{2}{*}{ Learning English } & $\mathrm{R}$ & $.403^{* *}$ & $.386^{* *}$ & .045 & $.266^{* *}$ \\
\hline & sig & .000 & .000 & .312 & .000 \\
\hline \multirow{2}{*}{ Reading in English } & $\mathrm{R}$ & 1.000 & $.479^{* *}$ & .021 & $.207^{* *}$ \\
\hline & $\operatorname{sig}$ & . & .000 & .646 & .000 \\
\hline \multirow{2}{*}{$\begin{array}{l}\text { Reading aloud in } \\
\text { English }\end{array}$} & $\mathrm{R}$ & & 1.000 & $-.204^{* *}$ & $.185^{* *}$ \\
\hline & $\operatorname{sig}$ & & & .000 & .000 \\
\hline \multirow{2}{*}{$\begin{array}{l}\text { Reading silently in } \\
\text { English }\end{array}$} & $\mathrm{R}$ & & & 1.000 & $.132^{* *}$ \\
\hline & sig & & & & .003 \\
\hline \multirow{2}{*}{$\begin{array}{l}\text { Reading on the } \\
\text { internet in English }\end{array}$} & $\mathrm{R}$ & & & & 1.000 \\
\hline & sig & & & & \\
\hline
\end{tabular}

Correlational analysis was performed by applying Spearman's rank order test and it shows that there is a significant positive correlation between motivation for learning English and positive attitudes to: reading in English $(p=.000)$, reading aloud in English $(p=.000)$, and reading on the 
internet $(\mathrm{p}=.000)$. As for motivation for reading in English, it correlates positively with reading aloud in English $(\mathrm{p}=.000)$ and with reading on the internet $(p=.000)$. There is a significant negative correlation between motivation for reading aloud and motivation for reading silently $(p=.000)$. Interestingly, there is a significant positive correlation between motivation for reading aloud and motivation for reading on the internet $(p=.000)$. Not surprisingly, a positive correlation was found between the attitude to reading silently in English and reading on the internet in English, indicating that children who liked reading silently also liked to read on the internet.

These findings were also supported by the data collected in the prompted think-aloud protocols with the sub-sample of twelve participants. Successful readers reported they liked learning English and reading in English, thus confirming their attitudes already reported through the smiley questionnaire. Motivation of the sub-sample was revealed by the following statements: "When I read in English, I sometimes do not understand some words, but I still feel satisfied. Reading in a foreign language somehow differs from reading in Serbian, it is more beautiful." (L-1-1-108); "I do love reading in English" (L-2-2-1-15); "I love reading both in Serbian and in English." (L-3-1-3-16). Less successful L2 readers reported: "I read in Serbian when I choose to do it. I take two to three books from the library a month, and I finish each of them in four to five days. But I do not read books or stories in English, I only read and translate coursebook texts." (L-3-1-3-05). The interviews also revealed that a preference for silent reading always correlated with highly fluent independent reading, while reading aloud was preferred by both less fluent and fluent readers.

All these findings are in line with the results of previous research showing that motivation, attitudes, and extensive reading are significant for reading skill development and linguistic achievements of young learners (Drew 2009; Lefever 2010; Lopriore and Krikhaar 2011; Macaro and Erler 2008; Mihaljević Djigunović 2013; Mihaljević Djigunović and Lopriore 2011; Munoz and Lindgren 2011; Nikolov 1999).

\section{Conclusion}

The study indicates that children's proficient performance in reading in English is very strongly associated with motivation, which corroborates 
previous studies. Reading comprehension results of beginning EFL readers are greatly affected by motivation for and attitudes to reading in English. As reported above, motivation for learning English and for reading in English, as well as positive attitudes to reading aloud and to reading on the internet, significantly correlate with reading achievement of young learners. Crucially, all children with high motivation and positive attitudes achieved better in the reading test. These findings appear to be well supported by previous research of the impact of young learners' attitudes on their linguistic outcomes.

Since the development of positive attitudes to and motivation for L2 learning may be considered as the main benefit of teaching languages at primary level (Cable et al. 2010,4), it is crucial to nurture children's positive attitudes and help them strengthen their motivation for reading in English in general, and for different modes of reading in English in particular. Teachers of beginning reading should, therefore, try to create rewarding reading experiences that can assist children in developing a sense of achievement, like readers theatre, role play, or reading picture books. Moreover, teachers should provide more opportunities for authentic reading experiences, give children the necessary guidance for internet reading, and help children become autonomous readers. This will in turn lead to much better academic and career prospects for young learners when they grow up and become highly proficient EFL readers.

\section{Bibliography}

Cable, Carrie, Patricia Driscoll, Rosamond Mitchell, Sue Sing, Teresa Cremin, Justine Earl, Ian Eyres, Bernardette Holmes, Cynthia Martin, and Barbara Heins. 2010. Languages learning at key stage 2 - A longitudinal study. Great Britain: The Open University, University of Southampton, Canterbury Christ Church University. Ofsted, Modern Languages - Achievement and challenge 2007-2010.

Dörnyei, Zoltan, and Kata Csizér. 1998. "Ten commandments for motivating language learners: results of an empirical study." Language Teaching Research 2 (3): 203-229. 
Dörnyei, Zoltan. 2014. "Motivation in second language learning". In Teaching English as a second or foreign language, edited by Marianne Celce-Murcia, Donna M. Brinton and Marguerite Ann Snow, 518531. Boston, MA: National Geographic Learning/Cengage Learning. Drew, Ion. 2009. "Using the Early Years Literacy Programme in primary EFL Norwegian classrooms." In Early learning of modern foreign languages: Processes and outcomes, edited by Marianne Nikolov, 108-120. Bristol: Multilingual Matters.

Edelenbos, Peter, Richard Johnstone, and Angelika Kubanek. 2006. The main pedagogical principles underlying the teaching of languages to very young learners. Languages for the children of Europe: Published research, good practice and main principles. http//ec.europa,eu/education/policies/lang/doc/youngsum_en.pdf.

Enever, Janet, ed. 2011. ELLiE: Early language learning in Europe. London: The British Council.

Enever, Janet. 2009. "Can today's early language learners in England become tomorrow's plurilingual European citizens?” In Early learning of modern foreign languages: Processes and outcomes, edited by Marianne Nikolov, 15-29. Bristol: Multilingual Matters.

Grabe, William, and Fredricka L. Stoller. 2011. Teaching and researching reading, 2nd ed. Great Britain: Pearson Education Limited.

Graddol, David. 2006. English next. British Council.

Lefever, Samuel. 2010. "English skills of young learners in Iceland: 'I started talking English when I was 4 years old. It just bang... just fall into me." Ráðstefnurit Netlu - Menntakvika 2010. Menntavísindasvið Háskóla Íslands. http://netla.hi.is/menntakvika2010/021.pdf. Lopriore, Lucilla, and Evelien Krikhaar. 2011. "The school." In ELLiE: Early language learning in Europe, edited by Janet Enever, 61-78. London: The British Council.

Macaro, Ernesto, and Lynn Erler. 2008. "Raising the achievement of young-beginner readers of French through strategy instruction." Applied Linguistics 29 (1): 90-119.

McKay, Penny. 2006. Assessing Young Language Learners. Cambridge: Cambridge University Press.

Mihaljević Djigunović, Jelena. 2013. "Early EFL learning in context Evidence from a country case study." British Council ELT Research Papers, Vol. 1: 159-182. 
Mihaljević Djigunović, Jelena. 2014. "Developmental and interactional aspects of young EFL learners' self-concept". In Studies in honour of Marianne Nikolov, edited by Jozsef Horvath and Peter Medgyes, 53-72. Pecs: Lingua Franca Csoport.

Mihaljević Djigunović, Jelena, and Lucilla Lopriore. 2011. "The learner: Do individual differences matter?" In ELLiE: Early language learning in Europe, edited by Janet Enever, 43-59. London: The British Council.

Munoz, Carmen, and Eva Lindgren. 2011. "Out-of-school factors - the home." In ELLiE: Early language learning in Europe, edited by Janet Enever, 103-123. London: The British Council.

Nikolov, Marianne. 1999. "'Why do you learn English?' 'Because the teacher is short.' A study of Hungarian children's foreign language learning motivation." Language Teacher Research 3 (1): 33-56.

Nikolov, Marianne. 2009. "Early modern foreign language programmes and outcomes: factors contributing to Hungarian learners' proficiency." In Early learning of modern foreign languages: Processes and outcomes, edited by Marianne Nikolov, 90-107. Bristol: Multilingual Matters.

Oxford, Rebecca L. 2005. "Anxiety and the language learner: New insights". In Affect in language learning, edited by Jane Arnold, 5867. Cambridge: Cambridge University Press.

Piniel, Katalin, and Ágnes Albert. 2017. 'L2 Motivation and Self-efficacy's Link to Language Learners' Flow and Antiflow Experiences in the Classroom." In UZRT 2016 Empirical Studies in Applied Linguistics, edited by Stela Letica Krevelj and Renata Geld, 90-103. Zagreb: FF Press.

Pinter, Annamaria. 2011. Children learning second languages. Basingstoke: Palgrave Macmillan.

Rasinger, Sebastian M. 2008. Quantitative research in linguistics. An introduction. London: Continuum International Publishing Group.

Savić, Vera. 2014. "Investigating reading skills of Serbian young learners learning English as a foreign language." In Conference proceedings from Early Language Learning: Theory and Practice 2014, edited by Janet Enever, Eva Lindgren and Sergej Ivanov, 108-114. Umea: Umea University.

Savić, Vera, and Vladimir Stanojević. 2016. "Young reader's self-esteem and success in reading in English as a foreign language." In Improving Quality of Elimentary Education, edited by Jelena Teodorović, 350-362. Jagodina: Faculty of Education. 
Saville-Troike, Muriel. 2006. Second language acquisition. Cambridge: Cambridge University Press.

Szpotowicz, Magdalena, and Eva Lindgren. 2011. "Language achievements: a longitudinal perspective." In ELLiE: Early Language Learning in Europe, edited by Janet Enever, 125-142. London: The British Council.

Wang, Judy Huei-Yu, and John T. Guthrie. 2004. "Modelling the effects of intrinsic motivation, extrinsic motivation, amount of reading, and past reading achievement on text comprehension between U.S. and Chinese students." Reading Research Quarterly 39 (2): 162-186.

\title{
Vera Savić
}

\section{MOTIVACIJA UČENIKA MLAĐEG UZRASTA ZA ČITANJE NA ENGLESKOM JEZIKU I POSTIGNUĆA U ČITANJU}

\begin{abstract}
Sažetak
Akademski i profesionalni uspeh nikada nije u toliko velikoj meri zavisio od pismenosti na engleskom kao stranom ili drugom jeziku (L2) kao danas. Čitanje je postalo ključna veština za učenje prvenstveno zbog brzog tehnološkog razvoja i velikog broja informacija dostupnih na internetu, pa se u današnje vreme očekuje da čak i učenici mlađeg školskog uzrasta razvijaju veštinu čitanja na engleskom jeziku. S obzirom na to da istraživanja pokazuju da samopouzdanje i motivacija učenika utiču na njihova lingvistička postignuća, cilj ovog rada bio je da ispita kako motivacija učenika mlađeg uzrasta doprinosi razvoju veštine čitanja i postignućima u čitanju. Istraživanjem je obuhvaćeno 502 učenika mlađeg školskog uzrasta (starosti 11 godina, peti razred osnovne škole) u šest državnih osnovnih škola iz pet geografski udaljenih gradova u Srbiji. Merenje motivacije i sposobnosti čitanja vršeno je kvantitativno i kvalitativno. Korelaciona analiza kvantitativnih rezultata pokazala je da postoji statistički značajna razlika u postignućima u čitanju na engleskom jeziku u zavisnosti od motivacije za učenje L2, i u zavisnosti od stavova ispitanika prema različitim aspektima L2 čitanja, dok su intervjui sa poduzorkom pokazali da je motivacija ključni faktor koji utiče na ekstenzivno čitanje i razvoj fluentnosti u čitanju na engleskom jeziku. Ovi rezultati ukazuju na izuzetno značajnu ulogu motivacije za razvoj pismenosti na stranom ili drugom jeziku, i imaju značajne pedagoške implikacije.
\end{abstract}

Ključne reči: učenici mlađeg uzrasta, motivacija za čitanje na engleskom jeziku, početno čitanje, postignuća u čitanju, verbalni protokol. 